\title{
0104. Modulatory effects of heat shock with or without glutamine compared to LPS on peripheral blood mononuclear cells heat-shock- protein $90 \alpha$ expression in severe sepsis and trauma
}

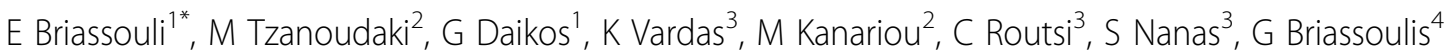

From ESICM LIVES 2014

Barcelona, Spain. 27 September - 1 October 2014

\section{Introduction}

Inflammatory stimuli cause posttranslational modifications of inducible $90 \alpha$-kDa-heat-shock-protein (HSP90 $\alpha$ ) that are Hsp90-inhibitor sensitive and may be important to the pro-inflammatory actions of Hsp90 $\alpha$.

\section{Objectives}

We investigated the heat-shock (HS) and lipopolysaccharide (LPS)-stress response effect on HSP90 $\alpha$ in cultured peripheral blood mononuclear cells (PBMCs) from patients with severe sepsis (SS) or trauma-related systemic inflammatory response syndrome (SIRS) compared to healthy-controls $(\mathrm{H})$ and any possible modulating Glutamine (Gln)-effect.

\section{Methods}

PBMCs of $16 / \mathrm{H}, 11 / \mathrm{SS}$, and $7 /$ SIRS were incubated with $1 \mu \mathrm{g} / \mathrm{ml}$ LPS or $43^{\circ} \mathrm{HS}$ vs.no stimulation for $4 \mathrm{~h}$. In each group 3 experiments involved L-Ala-Gln10mM incubation $1 \mathrm{~h}$ before (Gln-b) or after (Gln-a) induction, or no glutmanine (1088 measurements). Intracellular Mean Fluorescence Intensity (MFI) levels of monocytes (mHSP90 $\alpha$ ) or lymphocytes (lHSP90 $\alpha$ ) determined using Flow Cytometry.

\section{Results}

Baseline mHSP90 $\alpha$ was higher in SIRS $(187 \pm 30$ vs. 112 $\pm 10, \mathrm{p}<0.01)$ and $1 \mathrm{HSP} 90 \alpha$ in SS $(91 \pm 19$ vs. $47 \pm 3$,

${ }_{1}^{1}$ st Department of Propaedeutic InternalMedicine, University of Athens, Athens, Greece

Full list of author information is available at the end of the article $\mathrm{p}<0.001)$ compared to H. LPS induced H-mHSP90 $\alpha$ $(141 \pm 12$ vs. $112 \pm 10, \mathrm{p}<0.001)$ and HS H-lHSP90a ( $66 \pm 7$ vs. $47 \pm 3, p<0.0001)$. Neither LPS nor HS exhibit any significant effect in SIRS- or SS-mHSP90 $\alpha$ or lHSP90 $\alpha$. Glutamine given before LPS suppressed SS-1HSP90 $\alpha$ (Gln-b $61 \pm 5$ vs. $91 \pm 19, \mathrm{p}<0.004$ ). Similarly, when glutamine was given before or after HS suppressed SS-lHSP90 $\alpha$ (Gln-a $73 \pm 5$ vs. $91 \pm 19$, p $<0.001$; Gln-b $78 \pm 4$ vs. $91 \pm 19$, $\mathrm{p}<0.05)$, respectively.

\section{Conclusions}

PBMCs express higher baseline mHSP90 $\alpha$ in SIRS and lHSP90 $\alpha$ in SS, not further induced by LPS or HS, contrasting their induction effects in $\mathrm{H}$. Gln pre-treatment may attenuate the LPS or HS-induced lHSP90 $\alpha$ in SS.

\section{Grant acknowledgment}

This research has been co-financed by the European Union (European Social Fund (ESF)) and Greek national funds through the Operational Program "Education and Lifelong Learning" of the National Strategic Reference Framework (NSRF)-Research Funding Program: THALES.

\section{Authors' details}

${ }^{1} 1$ st Department of Propaedeutic InternalMedicine, University of Athens, Athens, Greece. ${ }^{2}$ Department of Immunology - Histocompatibility, Specialized Center \& Referral Center for Primary Immunodeficiencies Paediatric Immunology, "Aghia Sophia" Children's Hospital, Athens, Greece. ${ }^{3}$ First Critical Care Department, University of Athens, Evangelismos Hospital, Athens, Greece. ${ }^{4} \mathrm{PICU}$, University of Crete, University Hospital, Heraklion, Greece.

\section{Published: 26 September 2014}

(C) 2014 Briassouli et al; licensee Springer. This is an Open Access article distributed under the terms of the Creative Commons Attribution License (http://creativecommons.org/licenses/by/2.0), which permits unrestricted use, distribution, and reproduction in any medium, provided the original work is properly cited. 
doi:10.1186/2197-425X-2-S1-P14

Cite this article as: Briassouli et al.: 0104. Modulatory effects of heat shock with or without glutamine compared to LPS on peripheral blood mononuclear cells heat-shock-protein $90 \alpha$ expression in severe sepsis and trauma. Intensive Care Medicine Experimental 2014 2(Suppl 1):P14.

\section{Submit your manuscript to a SpringerOpen ${ }^{\mathcal{O}}$ journal and benefit from:}

- Convenient online submission

- Rigorous peer review

- Immediate publication on acceptance

- Open access: articles freely available online

- High visibility within the field

- Retaining the copyright to your article

Submit your next manuscript at $\gg$ springeropen.com 